\title{
Reform and Practice of Practice Teaching for Primary Education Specialty
}

\author{
Zijian Guo \\ Feixian Campus \\ Linyi University \\ Linyi, China \\ guozijian@lyu.edu.cn
}

\author{
Xuehua Jiang \\ School of Automation and Electrical Engineering \\ Linyi University \\ Linyi, China \\ jxhyx@163.com
}

\begin{abstract}
With the development of the new curriculum reform, the requirements for primary school teachers will be further improved in the future. The rationality of the structure of practical teaching content is directly related to the professional level of students in normal schools. It is necessary to set up the content of practice teaching in primary education specialty scientifically and improve the method of practice teaching, which can effectively improve the professional quality of students and improve the training quality of primary school teachers.
\end{abstract}

Keywords-Primary education major; Practice teaching; Content structure; Training mode

\section{INTRODUCTION}

Practice teaching is a compulsory teaching link for students with different majors in colleges and universities. The content of practical teaching in primary education specialty mainly includes four parts: speaking Mandarin Chinese and oral expression, writing standard Chinese characters and written expression, teaching work, head teachers' working skills, etc. Practical teaching is especially important to cultivate students' teaching ability. Therefore, attaching great importance to practice links and improve students' practical ability is inevitable requirement for deepening the teaching reform of primary education specialty and improving students' teaching ability [1].

The goal of teaching practice in primary education specialty is that the students can use the basic principles and methods of the teaching panning, teaching implementation and teaching evaluation in primary school teaching practice to implement the teaching work.

In recent years, the reform of teacher qualification system and teacher recruitment system are implemented step by step in China. It requires normal school graduates to take part in and pass the national teacher qualification examination and the local open teacher recruitment examination.

The Ministry of Education of China clearly stipulates that to optimize the structure of teacher education curriculum and the educational practice curriculum shall not be less than one semester. However, at present, the training mode of major in primary education is not perfect, the practice teaching has not

This study was supported by the Teaching Quality Engineering Projects of Linyi University in 2016, 2017 and 2018 been paid enough attention.

Practice teaching has become the weakest link in the training process of undergraduate primary school teachers. However, the value of educational practice is irreplaceable for primary school teacher training.

Therefore, it is of great significance to strengthen the practical teaching for the primary education specialty for the development of practice teaching of undergraduate primary education specialty and the setting up of professional curriculum system.

\section{The NeCESSITY OF PraCtice TEACHING IN PRIMARY EDUCATION}

\section{A. The requirements of education reform for new primary school teachers}

With the deepening of the basic education reform, higher requirements are put forward for the quality of teacher training. The traditional normal education can not meet the needs of the social development and the education reform. Based on the target of cultivating applied talents, it is necessary to reconstruct the practical teaching content system of primary education specialty and pay attention to the cultivation of teachers' quality.

It requires to make fundamental changes in professional setting, training mode, practical teaching, etc., especially in terms of vocational skills training and assessment standards. It can improve students' basic and professional skills needed for general primary education [2].

\section{B. The quality requirements for new teachers in teaching units}

It is necessary to strengthen the curriculum for promoting professional knowledge, such as word learning, language expression, children psychology, communication art, head teacher management, teaching research. The curriculum should be more close to the actual needs of primary school work, and the teachers should strengthen the teaching of basic knowledge and skills.

The school should pay attention on the teachers training of organizational and managerial skills. The emphasis is on strengthening the ability of teaching and student management in primary education. 


\section{Practical teaching is an effective way to improve students' teaching basic skills}

Some skills, such as the ability to think, the ability to express orally and the ability to organize teaching activities, are the key factors that affect education and teaching. Therefore, teachers' basic abilities are the most basic vocational skills that teachers must possess in education and teaching. In the training of primary education specialty, teachers are trained in vocational skills through practical teaching, so that they can learn and train systematically in school, experience the teaching situation in the future, and master some basic laws and methods of necessary educational skills.

Through the process of understanding from theory to practice, the basic skills and abilities of education have been formed. This can make the students complete the role transformation from students to teachers smoothly and become qualified primary school teachers [3].

\section{The CURRENT SituAtion OF PRACTICE TEACHING IN PRIMARY EDUCATION}

\section{A. The course design in practice Teaching is deficient}

The primary education undergraduate major focuses on the promotion of educational theory, but teachers' vocational skill training is relatively weak. Professional courses, including pedagogy, psychology, educational research methods, primary school Chinese teaching and research, primary school mathematics teaching research, teachers' oral English, calligraphy and educational apprenticeships, educational practice courses, educational activity courses, etc.

Special educational courses, etc. However, the allocation of class hours in practice teaching is unreasonable, which leads to the imbalance between practice teaching and theory teaching. The practice teaching only manifests for the education probation, the practice, the time asks short and the arrangement disperses. Education apprenticeship is basically equal to the practice of education.

Although the time question is long, the education practice time question is often formalized because of the conflict with the student seeking job. This kind of curriculum has led students to learn more educational and teaching theories, but the lack of training of teaching practice ability can not guarantee the improvement of teachers' professional quality as a whole.

\section{B. The management of practice teaching is deficient}

Practice teaching in primary education is a systematic project, which needs to be arranged scientifically and reasonably in time and space. Because practice teaching involves many departments, the division of labor and cooperation among each other often lacks initiative and enthusiasm, and the arrangement of practice teaching is lack of harmony and unification.
At present, the construction of practice teaching base of primary education major is generally insufficient, which leads to the lack of centralized practical teaching in primary education specialty, and the effect of practical teaching is not good. In the aspect of examination, because the division of practical teaching items is not specific enough and the quality standard of assessment is not perfect, the assessment of practical teaching is looser [4].

\section{Insufficient teacher resource in practice teaching}

Practice teaching is a special form of teaching in colleges and universities which need the guide of the teachers. However, many colleges and universities regard practice teaching as the independent study of students, thus neglect the allocation and training of teachers in professional practice teaching for a long time. The teachers pay more attention to teaching and scientific research, pay less attention to students' practical teaching.

\section{Insufficient support for practical Teaching in Schools}

Some normal college students often have only tests and no guidance for their teacher skills. The reasons are that there are no comprehensive guidance plans, no system for calculating workload, no specialized training facilities, and no adequate funds for investment.

Therefore, it is not surprising that teachers' skill training is a phenomenon of formality. The phenomenon that the vocational skill training of normal students of undergraduate primary education major is not in place still exists in a certain range at present, which must be attached great importance to by the training units. Teachers' vocational skills training must be carried out in a planned, organized and systematic manner, in line with the actual situation, to ensure that students are strictly trained and trained while they are in school. Examination.

\section{Practice Teaching Strategies For Primary EDUCATION SPECIALTY}

\section{A. Establish and perfect the professional practice teaching guarantee mechanism}

The competent departments and leaders of the school must correctly understand the importance of teachers' vocational skill training to normal students and attach great importance to it, and further improve the safeguard mechanism of skills training, including the arrangement of skills training courses, training places and facilities, the implementation of the construction of teaching staff. The arrangement of skills training courses is the foundation of training, and the establishment and stability of high quality and specialized skills training teachers is the guarantee of the sustainable development of training work.

The installation of advanced hardware facilities is the guarantee of the achievement of teachers' vocational skill training. The organic combination of the full-featured practical training center and a stable practice base outside school can enable the study of educational theory and the training of learning skills are more targeted [5]. 


\section{B. Establish a systematic and open practice teaching system}

The system of practice teaching should be systematic and open, and the form of practice teaching should be diversified and rich. In the training of teachers' vocational skills, it is necessary to make and make full use of various media, such as audio and video, to demonstrate teachers' vocational skills to students, and to give timely feedback on the training results. We should attach importance to arousing the enthusiasm of students to participate in skills training, so that students actively participate in the training.

We should make every effort to combine classroom teaching with extracurricular activities, combine students' independent training with centralized training, combine general skill training with discipline teaching skills training, combine traditional media teaching with modern educational technology teaching, combine the college training with primary school practice, so as to improve the effectiveness of teachers' vocational skills training.

It is necessary to strengthen the contact with the primary school, set up and make good use of the vocational skill practice training base, create the condition to let the normal school students understand as soon as possible, contact with the teaching practice of the primary school education, strengthen the actual effect of the skill training.

\section{Perfect the professional practice teaching items}

It is necessary to optimize and perfect the practical teaching items, clarify the contents, standards and specific requirements of the training items to facilitate individual training. The training manual can be compiled and issued to each student, so that it can become the learning goal of the students, becoming the motive force of autonomous training and autonomous learning.

For example, the skills are divided into Mandarin Chinese skills, oral expression, writing expression, teaching design, modern educational technology, classroom teaching implementation skills, class evaluation skills, organizing and guiding comprehensive activity skills, teaching research skills, head teachers working skills. The student can design the teaching plan that meets the requirements of the new curriculum reform.

The teachers can carry out new curriculum reform, have the ability to design and hold thematic class meetings as required. Each activity has specific standards and requirements [6].

\section{Provide rich teaching resources}

Video resource is a necessary condition for video viewing teaching. The major of primary education should set up a rich video database about primary school classroom teaching for students, and provide abundant resources for students to conduct video observation teaching. It provides necessary guarantee conditions for students to observe teaching spontaneously.

It is necessary to prepare a variety of video resources according to the objectives and contents of the observation teaching. For example, the excellent video resources in primary school are used to study the teaching design and the observation and teaching of the lessons; the excellent video resources for primary school teachers in different subjects are used to study the observation and teaching of classroom teaching, the excellent video resources are used for the observation and teaching of learning teaching evaluation, and so on.

\section{E. Build high level of practice teaching faculty}

The teaching staff is an important factor in practical teaching. Whether it is to organize and guide the normal school students to observe the teaching, or to train of teaching design, teaching implementation and evaluation, or to direct the teaching practice, it is necessary to have enough guidance teachers.

Teachers should be responsible for the development of normal students' teaching ability and be able to effectively organize and guide their practical teaching. It is need to select the teachers with strong sense of responsibility, high ability to guide students.

\section{F. Establish scientific assessment mechanism for practice teaching}

Perfect rules and regulations, strict training and inspection, standard training and assessment, can form a strict skill evaluation mechanism, fundamentally mobilize the initiative and enthusiasm of students to participate in teachers' vocational skills training. The high quality of extracurricular training can not be separated from the strict supervision and management of the inspection system.

The system has both supervision and guidance to skill training. The results are assessed according to the assessment standard. If students do not take part in the training, the results of this project will be regarded as unqualified.

Students can only participate in educational practice through qualified examination of the prescribed skills. Individual evaluation items, such as classroom teaching implementation skills, may invite excellent primary school teachers to participate in the evaluation and acceptance.

\section{CONCLUSION}

The practice teaching of primary education major is a complex systematic project, which involves the operation mechanism of the training of students' teaching vocational skills, the training equipment, the investment of funds, and so on, which requires the unified planning of all relevant units and their respective responsibilities.

In order to improve the vocational skill training level of normal college students, we should carry out demonstration instruction, practice exercise, strict examination and other steps of personnel training based on the clear objectives. Reconstructing the system of vocational skills training content for primary school teachers is a practical exploration to meet the needs of the professional development of rural primary school teachers under the background of the basic education curriculum reform. It still needs to be done and improved in teaching practice of the further research. 


\section{ACKNOWLEDGMENT}

This study was supported by the Teaching Quality Engineering Projects of Linyi University in 2016, 2017 and 2018.

\section{REFERENCES}

[1] Z. Cai, An Exploration of Reform in Practical Teaching for Undergraduate Elementary Education Program, Educational Research. (12) (2011) 99-102.

[2] X. He, Entire Practice: The Idea and Practice of the Construction of Professional Practice Courses in Primary Education, Higher Education Forum. (3) (2014) 78-81.

[3] W. Guan, Reform on the Practice (undergraduate) Curriculum of Primary Education, Journal of Shenyang Normal University (Social Science Edition). 31 (2007) 21-24.

[4] Q. Qin, Research on the Training Model of Undergraduate Primary Education Specialty, Journal of Jimei University. 13, (3) (2012) 1-5.

[5] [5] H. Zhong, The Practical Teaching Model of Developing Different Specific Teaching Abilities in Different Stages: A case Study of Primary Education Major, Journal of Dezhou University. 33, (5) (2017) 85-90.

[6] G. Shao, On Teachers Professional Skills Training in Undergraduate Primary Education, Journal of Ningbo University (Education Science Edition). 22(1) (2011) 15-20. 